\title{
Laporan kasus berbasis bukti Efektifitas Pemberian Calcium Channel Blocker pada Perdarahan Subaraknoid Akibat Trauma Kepala
}

Irawan Mangunatmadja, Anton Dharma Saputra

Departemen Ilmu Kesehatan Anak Fakultas Kedokteran Universitas Indonesia Rumah Sakit Dr Cipto Mangunkusumo, Jakarta

Latar belakang. Efektifitas pemberian calcium channel blocker (CCB) pada pasien trauma kepala dengan perdarahan subaraknoid masih kontroversial.

Tujuan. Melakukan telaah kritis untuk melihat efektifitas CCB pada perdarahan subaraknoid.

Metode. Pencarian artikel dilakukan secara daring menggunakan instrumen kata kunci yang sesuai melalui basis data New England journal of medicine (NEJM), Pubmed dan Cochrane pada bulan Mei-Juli 2019.

Hasil. Didapatkan 2 artikel berupa studi meta-analisis dan laporan kasus. Hasil analisis sub-kelompok tSAH pada meta-analisis, tingkat kematian 23\% pada kelompok uji dan 32\% pada kelompok plasebo, tetapi perbedaan ini tidak bermakna secara statistik. Hasil studi kasus serial pemberian nimodipine oral pada pasien anak dengan perdarahan subaraknoid tidak mengurangi kejadian vasospasme serebral, ataupun infark.

Kesimpulan. Penggunaan nimodipin pada kasus perdarahan subaraknoid akibat trauma kepala masih dapat dipertimbangkan. Sari Pediatri 2020;22(4):243-51

Kata kunci: nimodipine, perdarahan subaraknoid, CCB, calcium channel blocker

\section{Evidence base case report Efectivity of Calcium Channel Blocker of Subarachnoid Haemorrhage in Traumatic Brain Injury}

Irawan Mangunatmadja, Anton Dharma Saputra

Background. The effectiveness of calcium channel blockers (CCB) administration in head trauma patients with subarachnoid hemorrhage remains controversial.

Objective. To conduct a critical study to observe the effectiveness of CCB in subarachnoid hemorrhage.

Methods. Searching for articles was done online using appropriate keywords through the New England Journal of Medicine (NEJM), Pubmed and Cochrane databases in May-July 2019.

Results. Two articles were obtained in the form of meta-analysis studies and case reports. Results of the tSAH subgroup analysis in the meta-analysis, the mortality rate was $23 \%$ in the test group and $32 \%$ in the placebo group, but this difference was not statistically significant. The results of serial case study of oral administration of nimodipine in pediatric patients with subarachnoid hemorrhage did not reduce the incidence of cerebral vasospasm, or infarction, Conclusions.

Conclusion. The administration of nimodipine in cases of subarachnoid hemorrhage due to head trauma can still be considered. Sari Pediatri 2020;22(4):243-51

Keyword: nimodipine, subarachnoid haemorrhage, CCB, calcium channel blocker

Alamat korespondensi: Irawan Mangunatmadja. Departemen Ilmu Kesehatan Anak Fakultas Kedokteran Universitas Indonesia Rumah Sakit Dr Cipto Mangunkusumo, Jakarta. Email: irawanma2802@gmail.com 
$\mathrm{T}$ rauma kepala merupakan masalah di seluruh dunia dan menjadi penyebab dari sebagian besar kematian dan disabilitas. ${ }^{1-3}$ Pada trauma kepala, terjadi cedera otak sekunder. Mekanisme yang terjadi adalah iskemik sekunder akibat vasospasme, oklusi fokal mikrovaskuler, dan kerusakan pembuluh darah itu sendiri. Iskemik sekunder menyebabkan kematian sel-sel neuron, edema otak dan peningkatan tekanan intrakranial sehingga memperburuk cedera otak. ${ }^{1}$ Pada pasien dengan perdarahan subaraknoid akibat aneurisma, calcium channel blocker (CCB) telah terbukti efektif untuk mencegah komplikasi iskemik sekunder karena dianggap memiliki sifat neuroprotektor..$^{1-3}$

Penelitian uji acak terkendali Head Injury Trial (HIT) yang menilai efek kegunaaan nimodipine pada kasus trauma kepala menunjukkan bahwa tidak ada penurunan angka kematian maupun disabilitas dari penggunaan nimodipine. Akan tetapi, dari penilaian subgrup analisis pada pasien dengan perdarahan subaraknoid pascatrauma, didapatkan efek positif dari penggunaan nimodipine. ${ }^{1}$ Akan tetapi, meta-analisis dari Mervyn D, dkk (2006) yang dipublikasikan the Lancet, memberikan hasil yang berbeda, yakni tidak didapatkan efek positif dari pemberian nimodipine pada kasus trauma kepala. ${ }^{2}$

Sampai saat ini CCB sendiri masih digunakan pada pasien kasus perdarahan subaraknoid akibat trauma kepala di Departemen Bedah Saraf RSUPN Cipto Mangunkusumo (RSCM), walaupun bukti yang ada masih kontroversial. ${ }^{2-3}$ Laporan kasus berbasis bukti ini bertujuan untuk mengetahui efektifitas pemberian CCB pada kasus perdarahan subaraknoid pada anak akibat trauma kepala.

\section{Ilustrasi kasus}

Seorang anak lelaki 5 tahun dibawa ke RSCM pada tanggal 7 Februari 2019. Pasien ditemukan dalam keadaan tidak sadar oleh pengasuh pasien. Pasien diduga terjatuh saat mencoba memanjat lemari. Saat ditemukan, pasien sempat kejang kurang dari 5 menit. Pada saat datang di IGD RSCM, Glasgow Coma Scale (GCS) pasien adalah 5 (E1M3V1) dan pasien mengalami kejang umum. Tekanan darah 145/70 mmHg (P99+5), frekuensi nadi $135 \mathrm{kali} / \mathrm{menit}$, laju pernafasan $30 \mathrm{kali} / \mathrm{menit}$. Doll/s eye movement masih baik. Kedua pupil mengalami dilatasi dengan refleks cahaya yang berkurang. Kedua ekstremitas spastik dengan peningkatan refleks tendon. Hasil CT-scan kepala tanpa kontras ditemukan perdarahan luas subdural pada regio frontotemporoparietal kanan. Pasien kemudian dilakukan kraniotomi evakuasi hematoma dan dirawat di Pediatric Intensive Care Unit (PICU). Hari ke-9 perawatan, dilakukan CTscan kepala ulang didapatkan area hipodens dengan dugaan edema serebri dengan diagnosis banding infark serebri dan perdarahan subaraknoid pada regio temporal. Pada hari ke-12 dilakukan CTangiografi dan didapatkan area hipoperfusi pada serebri kanan akibat penyempitan pembuluh darah dengan diagnosa banding tromboemboli. Selama pasien perawatan di PICU, disarankan untuk pemberian CCB (nimodipine) dari Departemen Bedah Saraf, karena masih kontroversial tidak diberikan. Setelah pasien di rawat selama lebih dari 2 bulan, akhirnya pasien meninggal dunia.

\section{Pertanyaan klinis}

Berdasarkan ilustrasi kasus di atas, muncul pertanyaan klinis sebagai berikut: apakah pemberian calcium channel blocker dapat mengurangi angka kematian ataupun disabilitas pada pasien dengan perdarahan subaraknoid pascatrauma (tSAH).

\section{Metode penelusuran literatur}

Prosedur pencarian literatur untuk menjawab masalah di atas adalah dengan menelusuri pustaka secara daring menggunakan instrumen pencari, New England journal

Tabel 1. PICO

\begin{tabular}{llll}
\hline Populasi $(\mathrm{P})$ & Intervensi $(\mathrm{I})$ & Pembanding $(\mathrm{C})$ & Hasil $(\mathrm{O})$ \\
\hline $\begin{array}{l}\text { Kasus perdarahan } \\
\text { subaraknoid pascatrauma }\end{array}$ & $\begin{array}{l}\text { Pemberian } \\
\text { nimodipine }\end{array}$ & $\begin{array}{l}\text { Pemberian } \\
\text { plasebo }\end{array}$ & $\begin{array}{l}\text { Penurunan angka kematian atau } \\
\text { disabilitas }\end{array}$ \\
\hline
\end{tabular}


of medicine (NEJM), Pubmed dan Cochrane pada bulan Mei-Juli 2019. Kata kunci yang digunakan adalah "calcium channel blocker", "nimodipine", "traumatic brain injury", dan "subarachnoid haemorrhage" (Tabel 2). Setelah artikel didapatkan, dilakukan seleksi dengan kriteria inklusi, yaitu bahasa pengantar adalah bahasa Inggris, publikasi dalam rentang waktu sepuluh tahun terakhir, serta penelitian pada manusia. Kriteria eksklusi meliputi studi berupa telaah artikel, artikel ganda, tanpa full text, dan protokol (Gambar 1). Setelah melalui proses seleksi, dua buah artikel tersedia dan ditelaah dengan memperhatikan validitas, kepentingan, dan penerapan pada pasien (Tabel 3). Levels of evidence ditentukan berdasarkan klasifikasi yang dikeluarkan oleh Oxford for evidence-based medicine.

\section{Hasil penelusuran literatur}

Dua buah artikel yang relevan terhadap pertanyaan klinis ditemukan setelah penelusuran literatur.

Telaah sistematis dan meta-analisis (2013): ${ }^{3} A$ meta-analysis of treating acute traumatic brain injury with calcium channel blockers (level of evidence 1a) oleh Xu dkk. Cakupan studi telaah sistematis terhadap sembilan studi yang dipublikasi pada tahun 1946-2013 yang bertujuan untuk melihat pengaruh pemberian CCB pada pasien dengan trauma kepala, dengan keluaran yang dinilai adalah mortalitas dan fungsi neurologi. Dari 9 uji klinis acak dengan total 2192 peserta yang memenuhi kriteria inklusi dimasukkan dalam meta-analisis, dua uji klinis menggunakan CCB nicardipine, ${ }^{4,5}$ dan tujuh uji klinis lainnya menggunakan $\mathrm{CCB}$ nimodipine. ${ }^{6-13}$

Efek CCB terhadap mortalitas dievaluasi antar kelompok, terdapat sebanyak lima RCT yang menyediakan data untuk hasil ini. Pada kelompok yang mendapat nimodipine didapatkan angka kematian/ mortalitas sebesar 23\% (150 dari 641), lebih rendah daripada kelompok plasebo 25\%(164 dari 650). Akan tetapi, tidak ada perbedaan yang signifikan secara statistik ( $\mathrm{n}=1337,5$ RCT, RR 0,93 CI 0,77-1,12). Tidak ada perbedaan yang signifikan secara statistik dalam tingkat mortalitas antara nicardipine $(n=46$,
2 RCT, RR 1,00 CI 0,28-3,63) ataupun nimodipine $\left(\mathrm{n}=1291,3\right.$ RCT, RR 0,93 CI 0,76-1,12). ${ }^{3}$

Dalam analisis sub-kelompok tSAH, hanya ada dua studi yang menggunakan nimodipine yang berakibat pada kematian. Tingkat kematian pada kelompok uji lebih rendah daripada kelompok kontrol, dengan 23\% pada kelompok uji dan 32\% pada kelompok plasebo, tetapi perbedaan ini tidak signifikan secara statistik $\left(\mathrm{n}=389,2\right.$ RCT, RR 0,73 CI0,53-1,02). ${ }^{3}$

Delapan studi memberikan hasil yang tidak diinginkan (kematian, status vegetative, atau disabilitas berat). Pada kelompok pengobatan, terdapat lebih sedikit hasil yang tidak diinginkan dengan tingkat $39 \%$ berbanding $41 \%$. Namun, perbedaan ini tidak signifikan secara statistik $(\mathrm{n}=2101,8$ RCT, RR 0,90 CI $0,76-1,08) .^{3}$

Tingkat hasil yang menguntungkan (pemulihan yang baik atau disabilitas sedang) juga menunjukkan tidak ada perbedaan yang signifikan antara kelompok, dengan tingkat heterogenitas yang cukup besar $\left(\mathrm{I}^{2}=\right.$ 52\%; $\mathrm{n}=1712$ RCT, RR 1,18 CI 0,72-1,95). ${ }^{3}$

Studi deskriptif serial kasus Nimodipine for prevention of cerebral vasospasm following subarachnoid haemorrhage in twelve children (level of evidence 4) oleh Heffren dkk ${ }^{14}$ (2014), menilai efek pemberian nimodipine terhadap dua belas anak dengan perdarahan subaraknoid dalam mencegah terjadinya vasospasme serebral. Penelitian dilakukan melalui rekam medis pasien anak yang terbukti didiagnosis perdarahan subaraknoid pada tahun 2005-2013 pada satu pusat kesehatan di Amerika. Subjek awal penelitian, 16 pasien berusia 3,5 sampai 17,3 tahun, dengan rerata usia 11,8 tahun. Kriteria eksklusi adalah pasien neonatus dan wanita hamil. Dosis nimodipine oral yang diberikan $1 \mathrm{mg} / \mathrm{kg} / 4 \mathrm{jam}$. Dalam penelitian 4 pasien diekslusi karena pasien dipindahkan ke rumah sakit lain. Pada penelitian ini didapatkan $8(67 \%)$ pasien mengalami vasospasme, lima di antaranya didapatkan vasospasme selama perawatan. Sementara sisanya $4(33 \%)$ pasien mengalami infark selama perawatan. Dari penelitian ini disimpulkan pemberian nimodipine oral pada pasien anak dengan perdarahan subaraknoid tidak mengurangi kejadian vasospasme serebral, ataupun infark jika dibandingkan dengan literatur pada studi dewasa. 
Tabel 2. Strategi pencarian yang dilakukan melalui Pubmed dan Cochrane

\begin{tabular}{|c|c|c|c|}
\hline $\begin{array}{l}\text { Portal } \\
\text { pencarian }\end{array}$ & Kata kunci & $\begin{array}{l}\text { Artikel yang } \\
\text { didapat }\end{array}$ & $\begin{array}{l}\text { Artikel yang } \\
\text { digunakan }\end{array}$ \\
\hline Pubmed & $\begin{array}{l}\text { ("nimodipine"[MeSH Terms] OR "nimodipine"[All Fields]) OR ("calcium channel } \\
\text { blockers"[Pharmacological action] OR "calcium channel blockers"[MeSH Terms] OR } \\
\text { ("calcium"[All Fields] AND "channel"[All Fields] AND "blockers"[All Fields]) OR } \\
\text { "calcium channel blockers"[All Fields]) AND ("brain injuries, traumatic"[MeSH } \\
\text { Terms] OR ("brain"[All Fields] AND "injuries"[All Fields] AND "traumatic"[All } \\
\text { Fields]) OR "traumatic brain injuries"[All Fields] OR ("traumatic"[All Fields] AND } \\
\text { "brain"[All Fields] AND "injury"[All Fields]) OR "traumatic brain injury"[All } \\
\text { Fields]) AND ("subarachnoid haemorrhage"[All Fields] OR "subarachnoid } \\
\text { hemorrhage"[MeSH Terms] OR ("subarachnoid"[All Fields] AND "hemorrhage"[All } \\
\text { Fields]) OR "subarachnoid hemorrhage"[All Fields]) AND English[lang] }\end{array}$ & 26 & 2 \\
\hline Cochrane & $\begin{array}{l}\text { Nimodipine OR calcium channel blockers AND traumatic brain injury AND } \\
\text { subarachnoid haemorrahage }\end{array}$ & 2 & 0 \\
\hline
\end{tabular}

Kriteria eksklusi:

- Tidak terdapat abstrak

- Telaah artikel

- Protokol

- Artikel original dalam bahasa Tiongkok.

- Penelitian pada hewan

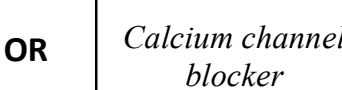

AND

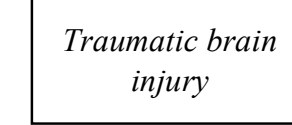

AND Subarachnoid haemorrhage

Batasan:

- Publikasi 10 tahun terakhir

- Artikel dalam bahasa Inggris
Artikel yang dapat digunakan $N=2$

Gambar 1. Diagram alur pemilihan literatur 
Irawan Mangunatmadja dkk: Efektifitas pemberian calcium channel blocker pada perdarahan subaraknoid akibat trauma kepala

Tabel 3. Karakteristik setiap studi yang dianalisis

\begin{tabular}{|c|c|c|c|c|c|}
\hline Studi & Durasi & $\begin{array}{l}\text { Jml. pasien } \\
\text { (pengobatan/ } \\
\text { plasebo) }\end{array}$ & Diagnosis & Intervensi & Hasil \\
\hline $\begin{array}{l}\text { Compton } 1990 \\
\text { (UK) }\end{array}$ & $24 \mathrm{jam}$ & $20 / 11$ & $\begin{array}{l}\text { Cedera kepala } \\
\text { berat }\end{array}$ & $\begin{array}{l}\text { Nicardipine vs plasebo. Dosis: awal } \\
2.5 \mathrm{mg} / \text { jam ditingkatkan menjadi } 7.5 \mathrm{mg} / \\
\text { jam apabila setelah } 4 \text { jam tidak responsif } \\
\text { - infus IV }\end{array}$ & $\begin{array}{l}\text { GOS; Doppler flow velocity } \\
\text { pada saat pemulangan dan } \\
3 \text { bulan. }\end{array}$ \\
\hline $\begin{array}{l}\text { HIT I } 1990 \text { (UK } \\
\text { dan Finlandia) }\end{array}$ & 1 minggu & $176 / 175$ & $\begin{array}{l}\text { Cedera kepala } \\
\text { berat }\end{array}$ & $\begin{array}{l}\text { Nimodipine vs plasebo. Dosis: awal } 1 \mathrm{mg} \\
\text { menjadi } 2 \mathrm{mg} / \mathrm{jam} \text { apabila tekanan darah } \\
\text { tidak menurun - IV }\end{array}$ & $\begin{array}{l}\text { GOS pada follow-up } 6 \\
\text { bulan }\end{array}$ \\
\hline $\begin{array}{l}\text { HIT II } 1994 \\
\text { (Eropa) }\end{array}$ & 1 minggu & $423 / 429$ & $\begin{array}{l}\text { Cedera kepala } \\
\text { berat }\end{array}$ & $\begin{array}{l}\text { Nimodipine vs plasebo. Dosis: awal } 1 \mathrm{mg} / \\
\text { jam menjadi } 2 \mathrm{mg} / \text { jam setelah } 2 \text { jam -IV }\end{array}$ & GOS pada 6 bulan \\
\hline $\begin{array}{l}\text { HIT II } 1996 \\
\text { (Jerman) }\end{array}$ & 3 minggu & $63 / 60$ & $\begin{array}{l}\text { Perdarahan } \\
\text { subaraknoid } \\
\text { traumatik }\end{array}$ & $\begin{array}{l}\text { Nimodipine vs plasebo. Dosis: } 2 \mathrm{mg} / \mathrm{jam} \\
\text { IV selama } 7-10 \text { hari dilanjutkan oral } \\
360 \mathrm{mg} / \text { hari sampai hari ke- } 21\end{array}$ & $\begin{array}{l}\text { Skala rating disabilitas; } \\
\text { Indeks Barthel; GOS; } \\
\text { post-traumatik epilepsi } \\
\text { pada follow-up } 6 \text { bulan }\end{array}$ \\
\hline $\begin{array}{l}\text { HIT IV } 1999 \\
\text { (13 negara, } \\
\text { internasional) }\end{array}$ & 3 minggu & $290 / 287$ & $\begin{array}{l}\text { Perdarahan } \\
\text { subaraknoid } \\
\text { traumatik }\end{array}$ & Nimodipine vs plasebo & GOS pada 6 bulan \\
\hline $\begin{array}{l}\text { Sahuquillo } 2000 \\
\text { (Spanyol) }\end{array}$ & 1 minggu & $11 / 11$ & $\begin{array}{l}\text { Cedera kepala } \\
\text { berat }\end{array}$ & $\begin{array}{l}\text { Nicardipine vs plasebo. Dosis: } 5 \mathrm{mg} / \\
\text { jam -IV }\end{array}$ & $\begin{array}{l}\text { Kematian, kecacatan, } \\
\text { GOS; temporal evolution } \\
\text { dari middle cerebral artery } \\
\text { Doppler flow velocity } \\
\text { (DFV) pada baseline dan } \\
\text { hari ke- } 1,3,5 \text {, dan } 7\end{array}$ \\
\hline $\begin{array}{l}\text { Feng } 2000 \text { (Belgia } \\
\text { dan China) }\end{array}$ & 3 minggu & $45 / 44$ & $\begin{array}{l}\text { Cedera aksonal } \\
\text { difus }\end{array}$ & $\begin{array}{l}\text { Nimodipine vs plasebo. Dosis: awal } 1 \\
\text { mg/jam, ditingkatkan menjadi } 2 \mathrm{mg} / \mathrm{jam} \\
\text { apabila tidak responsif dalam } 2 \text { jam. } \\
\text { Setelah } 7-10 \text { hari, oral nimodipine } 60 \\
\mathrm{mg} / 4 \text { jam atau tablet plasebo selama } 21 \\
\text { hari }\end{array}$ & $\begin{array}{l}\text { TCD; GOS; hasil } \\
\text { memuaskan; hasil kurang } \\
\text { memuaskan dalam } 3 \\
\text { bulan }\end{array}$ \\
\hline Pillai 2003 (India) & 3 minggu & $50 / 47$ & $\begin{array}{l}\text { Cedera kepala } \\
\text { berat difus }\end{array}$ & $\begin{array}{l}\text { Nimodipine vs plasebo. Dosis: awal } \\
\text { diberikan 30mg setiap } 6 \text { jam selama } 3 \\
\text { minggu - oral }\end{array}$ & $\begin{array}{l}\text { GOS saat pemulangan, } \\
\text { dan dalam } 6 \text { bulan; } \\
\text { memori; personaliti; } \\
\text { fungsi kognitif lainnya; } \\
\text { integrasi sosial; bicara; } \\
\text { paresis; epilepsi }\end{array}$ \\
\hline $\begin{array}{l}\text { Farhoudi } 2007 \\
\text { (Iran) }\end{array}$ & $12 \mathrm{jam}$ & $20 / 20$ & $\begin{array}{l}\text { Cedera aksonal } \\
\text { difus }\end{array}$ & $\begin{array}{l}\text { Nimodipine vs perawatan standar. Dosis: } \\
\text { nimodipine } 60 \mathrm{mg} / 4 \text { jam dengan selang } \\
\text { pada } 12 \text { jam awal admisi }\end{array}$ & $\begin{array}{l}\text { Mean flow velocity (MFV), } \\
\text { indeks } \\
\text { pulsatil, } 1 \text { bulan kemudian } \\
\text { GOS }\end{array}$ \\
\hline
\end{tabular}

$\overline{\mathrm{GOS}}=$ Glasgow outcome scale $\mathrm{TCD}=$ Transcranial Doppler, 
Tabel 4. Telaah kritis (1)

\begin{tabular}{|c|c|}
\hline Artikel & $\mathrm{Xu} \mathrm{dkk^{3 }}$ \\
\hline $\begin{array}{l}\text { Desain } \\
\text { penelitian }\end{array}$ & telaah sistematis dan meta-analisis \\
\hline Level of evidence & $1 \mathrm{a}$ \\
\hline $\begin{array}{l}\text { PICO } \\
\mathrm{P} \\
\mathrm{I} \\
\mathrm{C} \\
\mathrm{O}\end{array}$ & $\begin{array}{l}\text { Pasien perdarahan subaraknoid akibat trauma } \\
\text { Calcium channel blocker } \\
\text { placebo } \\
\text { penurunan mortalitas }\end{array}$ \\
\hline Validity & $\begin{array}{l}\text { PICO } \\
\text { Pertanyaan klinis tergambar pada abstrak dan akhir paragraf pendahuluan, yaitu efek pemberian CCB } \\
\text { terhadap pasien dengan perdarahan araknoid akibat trauma kepala. } \\
\text { Missed relevant studies } \\
\text { Pencarian dilakukan secara sistematis dengan clinicaltrials.gov, pusat data Cochrane Library, EMBASE } \\
\text { (1980-2013), MEDLINE (1946-2013), pencarian web sains dan WHO Trial Registry. Peneliti juga } \\
\text { menghubungi semua peneliti utama atau penulis yang sesuai dari studi yang diidentifikasi. } \\
\text { Kata kunci yang digunakan pada pencarian ini: calcium channel blocker, calcium antagonist, verapamil, } \\
\text { nifedipine, nicardipine, amlodipine, felodipine, isradipine, Iacidipine, Ziconotide, nimodipine and diltiazem } \\
\text { traumatic brain injury, traumatic head injury, head injury, head trauma, brain injury, brain trauma. } \\
\text { Kriteria inklusi } \\
\text { Semua studi telaah sistematis dan uji klinis yang menilai pemberian CCB pada pasien dengan } \\
\text { perdarahan akibat cedera kepala. Keseluruhan abstrak yang diperoleh diseleksi oleh } 2 \text { orang, kemudian } \\
\text { dilakukan pencarian artikel full-text, dan seleksi studi. Perbedaan opini diantara keduanya akan } \\
\text { diselesaikan melalui diskusi kelompok, jika tidak mencapai kesepakatan hasil didiskusikan dengan orang } \\
\text { ke } 3 . \\
\text { Validitas dari studi yang dipilih } \\
\text { Penelitian ini menyertakan penilaian kualitas studi telaah sistematis dengan menggunakan Jadad scale } \\
\text { dan karakteristik masing-masing studi, namun tidak disebutkan kemungkinan bias yang terjadi. Hasil } \\
\text { tiap studi disajikan dalam tabel. Dan analisa statistic dalam forest plot.- } \\
\text { Hasil serupa antar studi } \\
\text { Hasil penelitian homogen, sesuai dengan telaah sistematis sebelumnya. } \\
\text { Kesimpulan: sahih }\end{array}$ \\
\hline Importance & $\begin{array}{l}\text { Telaah sistematis menunjukan tidak ada perbedaan pada kelompok uji CCB dan kelompok kontrol } \\
\text { dalam angka mortalitas. } \\
\text { Risk ratio } 0,93 \text { (n=1337, CI 95\%, 0,77-1,12) } \\
\text { Pada analisis subgrup pasien dengan tSAH, terdapat perbedaan angka mortalitas, walaupun tidak } \\
\text { signifikan. } \\
\text { Risk ratio } 0,73 \text { (n=389, CI 95\%, 0,53-1,02) } \\
\text { Kesimpulan: Pemberian calcium channel blocker menurunkan angka mortalitas walaupun secara statistik } \\
\text { tidak bermakna. }\end{array}$ \\
\hline Applicability & $\begin{array}{l}\text { Apakah sama dengan kondisi pasien? Ya } \\
\text { Apakah intervensi bisa dilakukan di tempat saya bekerja? Ya } \\
\text { Apakah keuntungan lebih besar dibandingkan kerugian? Ya } \\
\text { Kesimpulan: dapat diterapkan }\end{array}$ \\
\hline
\end{tabular}


Tabel 5. Telaah kritis (2)

\begin{tabular}{ll}
\hline Artikel & Heffren dkk $^{14}$ \\
\hline Desain penelitian & Serial kasus \\
\hline Level of evidence & 4 \\
\hline PICO & \\
$\mathrm{P}$ & Pasien anak dengan perdarahan subaraknoid \\
$\mathrm{I}$ & Nimodipine \\
$\mathrm{C}$ & Tidak ada \\
$\mathrm{O}$ & Vasospasme serebral \\
\hline Validity & Sampel representatif diambil pada titik yang sama dari suatu penyakit \\
& Ya, sebagian besar (83\%) pasien diambil kurang lebih dari titik yang sama dari suatu kejadian \\
& perdarahan subaraknoid setelah ditegakkan (<96jam) \\
& Pemantauan yang dilakukan cukup panjang dan terpenuhi \\
& Ya, pemantauan dilakukan selama pasien dirawat sampai pasien dipulangkan \\
& Kriteria luaran dinyatakan secara objektif atau tersamar \\
& Luaran utama pada penelitian ini adalah vasospasme yang dinilai secara objektif menggunakan \\
& angiografi \\
& Penyesuaian faktor prognostik pada subgroup yang terindentifikasi memiliki prognosis yang berbeda \\
& Tidak ada \\
& Kesimpulan: sahih \\
\hline Importance & Hasil studi. \\
& Angka kejadian vasospasme selama terapi profilaksis nimodipine sebesar 67\% (8 kasus). Angka infark \\
& baru 33\% (4 kasus), dan perdarahan ulang 17\% (2 kasus). \\
& Seberapa presisi hasil studi digambarkan. \\
& Hasil penilitian digambarkan secara deskriptif \\
& Kesimpulan: Pemberian nimodipine tidak menurunkan angka insiden dari vasospasme serebral \\
\hline & Apakah sama dengan kondisi pasien? Ya \\
& Apakah intervensi bisa dilakukan di tempat saya bekerja? Ya \\
& Apakah keuntungan lebih besar dibandingkan kerugian? Tidak \\
& Kesimpulan: dapat diterapkan \\
\hline Applicability & \\
&
\end{tabular}

\section{Pembahasan}

Cedera otak karena trauma kepala dapat menyebabkan gangguan homeostasis kalsium di otak dan menyebabkan peningkatan kadar $\mathrm{Ca}^{2+}$ dalam sel melalui kanal sensitif tegangan (voltage sensitive channel) sehingga membuat kerusakan iskemik sekunder. ${ }^{14-15} \mathrm{Hal}$ ini menyebabkan aliran darah ke otak menurun, tetapi konsumsi oksigen meningkat pada fase akut setelah terjadinya cedera otak berat. ${ }^{15}$ Pengurangan kelebihan $\mathrm{Ca}^{2+}$ akan mengurangi kerusakan otak sekunder sehingga cedera otak lanjut dapat dicegah. ${ }^{15}$ Namun, pasien dengan TBI memiliki gejala yang sangat heterogen, juga berbagai faktor yang memengaruhi, termasuk usia, derajat keparahan, mekanisme trauma, jenis cedera dan waktu inisiasi perawatan yang mungkin secara bermakna memengaruhi hasil. ${ }^{15}$ Oligemia, vasospasme, dan $\mathrm{SAH}$ merupakan kejadian yang umum terjadi setelah TBI; perdarahan subaraknoid traumatis terjadi pada $60 \%$ pasien dengan TBI yang dikaitkan dengan peningkatan dua kali lipat risiko kematian, ${ }^{2-3}$ dan merupakan salah satu faktor risiko prognostik buruk paling penting pada cedera kepala. ${ }^{2-3}$

Calcium channel blocker, terutama nimodipine, telah terbukti dapat mengurangi risiko kematian setelah SAH aneurismal; oleh karena itu, dilakukan studi untuk menyelidiki manfaat penggunaan CCB dalam pengobatan TBI., ${ }^{5,10}$ Sebuah tinjauan sistematis menyatakan tidak menemukan adanya efek benefisial yang bermakna dari CCB pada pasien dengan TBI secara keseluruhan. ${ }^{1}$ Namun, dalam subgrup pasien dengan tSAH, CCB secara bermakna menurunkan 
tingkat kematian dan disabilitas derajat berat. ${ }^{1} \mathrm{Hal}$ ini sesuai dengan studi lain yang menemukan bahwa efek restorasi nimodipine pada pasien dengan trauma kepala berat dengan gangguan metabolisme otak akan mencegah terjadinya cedera seluler dan meningkatkan kualitas hidup dengan mengurangi kerusakan neuron sekunder. ${ }^{15}$ Akan tetapi, studi meta analisias lain menyatakan bahwa tidak terdapat perbedaan hasil ataupun angka mortalitas yang bermakna antara peserta yang menerima nimodipine dan plasebo, CCB tidak menunjukkan efek menguntungkan yang bermakna pada pasien rawat inap dengan $\mathrm{tSAH}{ }^{2}$

Dari hasil telah sistematis oleh $\mathrm{Xu} \mathrm{dkk}^{3}$ menunjukkan angka kematian pada kelompok uji yang mendapatkan nimodipine didapatkan hasil yang lebih rendah, yakni 23\% dibandingkan 25\% pada kelompok plasebo. Hal ini tidak didapatkan pada penelitian yang menggunakan nicardipine. Akan tetapi, secara statistik tidak ada perbedaan dalam tingkat kematian pada pasien trauma kepala yang tidak dipilih - hal ini sesuai dengan ulasan oleh Langham dkk. ${ }^{2-3}$

Dalam analisis subkelompok tSAH, Langham dkk menerapkan analisis per-protokol yang mungkin telah mengesampingkan terjadinya kejadian buruk dan lebih banyak memperkirakan efek menguntungkan dari obat. ${ }^{1,3}$ Pada studi $\mathrm{Xu} \mathrm{dkk}^{3}$ telaah sistematis menerapkan analisis intention-to-treat (ITT) yang dapat mencegah hilangnya data penelitian dan menghindari bias yang disebabkan oleh atrisi, dan meningkatkan realibilitas kesimpulan. Dengan menggunakan analisis ITT, Xu dkk menemukan tidak ada perbedaan secara statistik antara kelompok untuk tingkat kematian pada pasien $\mathrm{tSAH}$-sesuai dengan temuan Vergouwen $\mathrm{dkk}^{2-3}$ Akan tetapi, pada kedua penelitian Xu dkk dan Vergouwen dkk didapatkan angka kematian yang lebih rendah pada subkelompok tSAH walaupun tidak berbeda bermakna secara statistik. Mengingat kematian adalah keluaran yang bermakna secara klinis, angka yang lebih rendah pada kelompok yang mendapatkan nimodipine bermakna bagi seorang klinisi. Apalagi mengingat angka yang lebih rendah pada subkelompok yang mendapat nimodipine didapatkan juga pada penelitian oleh Vergouwen dkk dan Langham dkk. ${ }^{1-3}$

Berdasarkan telaah sistematik Xu dkk dapat disimpulkan dari uji coba terkontrol acak yang ada, tidak mengidentifikasi efek menguntungkan yang bermakna secara statistik pada pasien TBI dan pasien dengan $\mathrm{tSAH} .{ }^{3}$ Akan tetapi, mengingat kematian/ mortalitas merupakan keluaran yang bermakna secara klinis penggunaan nimodipine dapat tetap dipertimbangkan.

Pada studi serial kasus oleh Heffren dkk, ${ }^{14}$ didapatkan dari 12 anak dengan perdarahan subaraknoid yang mendapat profilaksis nimodipione oral, angka kejadian vasospame $67 \%$ (8 anak), infark baru 33\% (4 anak) dan perdarahan ulang 17\%(2 anak). Pada serial kasus ini didapatkan tidak ada pasien anak yang meninggal selama perawatan. ${ }^{14}$

Pasien dalam kasus ini merupakan pasien anak dengan trauma kepala, saat dilakukan evaluasi CTscan lanjutan pada perawatan di PICU ditemukan adanya perdarahan subaraknoid. Pemberian CCB pada kasus perdarahan subaraknoid akibat trauma masih merupakan suatu kontroversi. Hasil studi yang ada saat ini masih memerlukan bukti yang lebih kuat untuk dapat diterapkan menjadi suatu panduan pemberian CCB pada pasien dengan perdarahan subaraknoid akibat trauma. Akan tetapi, mengingat kematian/ mortalitas merupakan keluaran yang bermakna secara klinis, penggunaan $\mathrm{CCB} /$ nimodipine dapat dipertimbangkan.

\section{Kesimpulan}

Hasil telaah kritis mendapatkan semua studi yang ada, menunjukan angka kematian yang lebih rendah pada kelompok uji yang mendapatkan nimodipine, walaupun secara statistik tidak bermakna. Oleh karena itu, penggunaan nimodipin pada kasus perdarahan subaraknoid akibat trauma kepala masih dapat dipertimbangkan.

\section{Daftar pustaka}

1. Langham J, Goldfrad C, Teasdale G, Shaw D, Rowan K. Calcium channel blockers for acute traumatic brain injury. Cochrane Database Syst Rev. 2003.

2. Vergouwen MD, Vermeulen M, Roos Y. Effect of nimodipine on outcome in patients with traumatic subarachnoid haemorrhage: a systematic review. Lancet Neurol 2006;5:102932.

3. Xu GZ, Wang MD, Liu KG, Bai YA, Wu W, Li W. A metaanalysis of treating acute traumatic brain injury with calcium channel blockers. Brain Res Bull 2013;99:41-7.

4. Compton JS, Lee T, Jones NR, Waddell G, Teddy PJ. A double blind placebo controlled trial of the calcium entry blocking drug, nicardipine, in the treatment of vasospasm following 
Irawan Mangunatmadja dkk: Efektifitas pemberian calcium channel blocker pada perdarahan subaraknoid akibat trauma kepala

severe head injury. Br J Neurosurg 1990;4:9-15.

5. Sahuquillo J, Robles A, Poca A, Ballabriga A, Mercadal J, Secades JJ. A controlled, double-blind, randomized pilot clinical trial of nicardipine as compared with a placebo in patients with moderate or severe head injury. Rev Neurol 2000;30:401-8.

6. Bailey I, Bell A, Gray J, Gullan R, Heiskanan O, Marks PV, dkk. A trial of the effect of nimodipine on outcome after head injury. Acta Neurochir (Wien) 1991;110:97-105.

7. Farhoudi M, Asghari M, Aghajanloo M, Zeinali A. Effects of nimodipine on cerebral hemodynamics, and prognosis of diffuse axonal injury patients. Neurosciences (Riyadh) 2007;12:285-8.

8. Feng D, Ma Y, Zhang Y, Plets C, Goffin J, Chen J. Controlled study of nimodipine in treatment of patients with diffuse axonal injury. Chin J Traumatol 2000;3:85-8.

9. European Study Group on Nimodipine in Severe Head Injury. A multicenter trial of the efficacy of nimodipine on outcome after severe head injury. J Neurosurg 1994;80:797-804.
10. Teasdale G, Bailey I, Bell A, dkk. A randomized trial of nimodipine in severe head injury: HIT I. British/Finnish Co-operative Head Injury Trial Group. J Neurotrauma 1992;9:545-50.

11. Harders A, Kakarieka A, Braakman R. Traumatic subarachnoid hemorrhage and its treatment with nimodipine. J Neurosurg 1996;85:82-9.

12. Kostron H, Rumpl E, Stampfl G, Russegger L, Grunert V. Treatment of cerebral vasospasm following severe head injury with the calcium influx blocker nimodipine. Neurochirurgia (Stuttg) 1985;28:103-9.

13. Murray GD, Teasdale GM, Schmitz H. Nimodipine in traumatic subarachnoid haemorrhage: a re-analysis of the HIT I and HIT II trials. Acta Neurochir (Wien) 1996;138:1163-7.

14. Heffren J, Mcintosh AM, Reiter PD. Nimodipine for the prevention of cerebral vasospasm following subarachnoid haemorrhage in twelve children. Pediatr Neurol 2015;52:356-60.

15. Nicholls DG, Budd SL. Mitochondria and neuronal survival. Physiol Rev 2000;80:315-60.

Lampiran tabel rangkuman studi

\begin{tabular}{|c|c|c|}
\hline \multirow[t]{2}{*}{ Parameter } & $\mathrm{Xu} \mathrm{dkk}^{3}$ & Heffren $\mathrm{dkk}^{14}$ \\
\hline & Level of evidence: $1 \mathrm{a}$ & Level of evidence: 4 \\
\hline Desain & Telaah sistematis dan meta analisis & Serial kasus \\
\hline Periode & Pencarian pada 2013 & 1 Januari 2005- 31 Agustus 2013 \\
\hline Lokasi & China & Amerika \\
\hline \multirow[t]{3}{*}{ Tujuan } & $\begin{array}{l}\text { Mengetahui efek pemberian calcium channel blocker pada } \\
\text { kasus trauma kepala. }\end{array}$ & $\begin{array}{l}\text { Mengetahui efek pemberian nimodipine dalam } \\
\text { mencegah vasospasme serebral }\end{array}$ \\
\hline & Penilaian utama: mortalitas dan fungsi neurologis & Penilaian: vasospasme serebral \\
\hline & $\begin{array}{l}\text { Penilian sekunder: kejadian yang tidak diinginkan, efek } \\
\text { samping, keluaran yang menguntungkan. }\end{array}$ & Penilaian sekunder: Insiden infark, kematian \\
\hline $\begin{array}{l}\text { Kriteria } \\
\text { inklusi }\end{array}$ & $\begin{array}{l}\text { - Tipe studi: uji klinis acak yang menilai efek pemberian } \\
\text { calcium channel blocker pada kasus trauma kepala } \\
\text { - Tipe partisipan: pasien trauma kepala } \\
\text { - Tipe intervensi: pemberian calcium channel blocker } \\
\text { - Tipe luaran: mortalitas, fungsi neurologis yang dinilai } \\
\text { dengan Glasgow outcome scale }\end{array}$ & $\begin{array}{l}\text { Pasien anak dengan perdarahan subaraknoid yang } \\
\text { berobat pada periode penilitian }\end{array}$ \\
\hline Partisipan & $\begin{array}{l}9 \text { uji klinis acak dengan total subjek sebanyak } 2182 \text { pasien } \\
\text { - Kelompok mendapatkan CCB: } 1098 \text { subjek } \\
\text { - Kelompok mendapatkan plasebo: } 1084 \text { subjek }\end{array}$ & $\begin{array}{l}12 \text { pasien anak, dengan berbagai penyebab } \\
\text { perdarahan subaraknoid }\end{array}$ \\
\hline Intervensi & $\begin{array}{l}2 \text { uji klinis acak menilai efek dari nicardipine } \\
7 \text { uji klinis acak menilai efek nimodipine }\end{array}$ & Nimodipine oral $1 \mathrm{mg} / \mathrm{kg} / 4 \mathrm{jam}$ \\
\hline Luaran & - Luaran primer: mortalitas, Glasgow outcome scale & - Luaran primer: vasospasme serebral \\
\hline Bias & $\begin{array}{l}\text { - Bias seleksi: cara penelusuran data tidak disertakan, } \\
\text { hanya melibatkan studi dari data elektronik }\end{array}$ & $\begin{array}{l}\text { - Bias sampel penelitian: data yang ada memiliki } \\
\text { karakteristik yang heterogen, dan memiliki } \\
\text { durasi terapi pemberian nimodipine yang ber- } \\
\text { beda antar kasus yang ada. Hanya satu pasien } \\
\text { yang memiliki usia di bawah } 5 \text { tahun }\end{array}$ \\
\hline
\end{tabular}

